\title{
Integrated Parking System For Troubleshooting Parking Location Search In Big City Based Internet Of Things (IoT)
}

\author{
Sukamto ${ }^{1}$, Wahyu Sulistiyo², Tri R Yudantoro³, Parsumo Rahardjo ${ }^{4}$, Dinda \\ Rhomadhona Ayuningtyas ${ }^{5}$, Muhammad Irsyadul lbad ${ }^{6}$ \\ Department of Electrical Engineering, State Polytechnic of Semarang
}

E-mail: suk4mto@gmail.com¹,w4hyu5@yahoo.com², tryudan@gmail.com³ ${ }^{3}$ dinda507@gmail.com4, kyosukeirlav@gmail.com ${ }^{5}$,

\begin{abstract}
Parking space is one of the important needs for vehicle owners.along with the increasing number of vehicles, especially in big cities have an impact on the difficulty of finding parking locations. Sometimes it takes a few minutes even hours just to find the location of available parking. This is the background of making Finding Parking. Application Finding Parking is an online parking search system based on the Internet of Things.on the parking location there are infrared sensors that aims to detect the presence of vehicles, data from existing sensors this parking location will be processed and sent to users who look for parking locations via Android to know the location of the nearest parking. The purpose of this Final Project is to help vehicle owners find available parking locations. Finding Parking application created by Waterfall method, Java programming language, MySQL database that is run by users through Android smartphone.Based on the tests that have been done can be obtained results that Finding Parking application is able to provide information to the owner of the vehicle regarding the availability of parking
\end{abstract}

locations.

Keyword - Parking, Android, Internet of Things

\section{Introduction}

Along with the rapidly evolving technological advancement today, the consumptive level of motor vehicle and motorcycle usage is particularly high especially in big cities in Indonesia such as Jakarta, Surabaya, Semarang, Bandung.data from the Police Office of the Republic of Indonesia show that the number of motor vehicle users has always increased by four percent annually.

The increase in the number of users of motor vehicles is directly proportional to the increasing need for parking lots, especially in big cities. Currently, most of the parking spaces are designed terraced.the purpose of the design is that the parking lot can still accommodate many vehicles, without the need for extensive land. Yet the multilevel parking lot also has a weak side of the user, ie, around each floor to get a parking lot that is still empty.

Most parking systems in Indonesia today still use the ticket system.the parking ticket only contains information about the vehicle number and parking price only, so there is no information about the location that the user used to put his vehicle. So if the user wants to park his vehicle must first round each floor to get a parking space. It is a waste of time and energy.another problem is the queue of parking area entrance which takes a long time because of having to queue get a ticket.

on the above issues, we have a practical solution to solve problems in searching for nearest parking location, parking payment and also reducing queue time by using Internet Based Things (IoT) based "Finding Parking" system.Internet of Things (IoT) technology utilizes internet connectivity that allows users to search parking locations. This is much more practical when compared to manual search as it can save time and effort.

\section{Research Methodology}

Method of making the system Finding Parking (Parking System Based Internet Based on Things) by using Waterfall method.this method is used to build Internet-based applications of Things to find the nearest parking location.

\subsection{Waterfall Method}

Waterfall method is a process of making apikasi in a structured and sequential starting from problem determination, needs analysis, design implementation, untegrasi, system test, application 
placement and maintenance.making applications with this method is very suitable to be done on largescale applications because it involves management and complicated systems.

This method requires a systematic and sequential approach in software development and is usually called classic life cycle, starting from the system level and progress through analysis, design, coding, testing and maintenance.stages waterfall method can be seen in Figure 2.1.

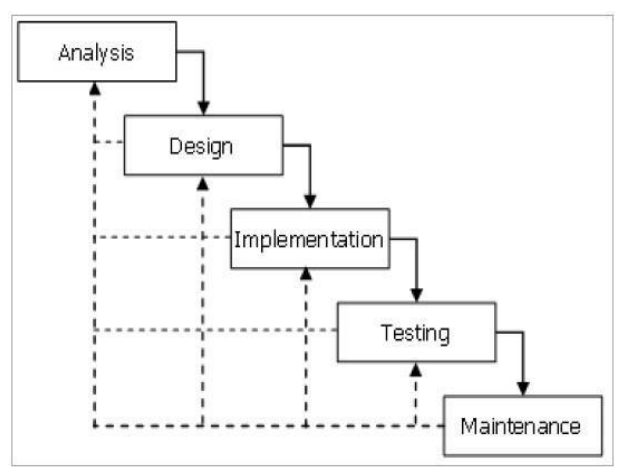

Figure 2. 1 Waterfall Diagram

\subsection{System Overview}

Finding Parking is a technology-based parking search application of the Internet of Things (IoT).this application is built using the Java programming language, while for data storage applications using MySQL database.

This parking system application has features such as login, register, search for parking space, provide information in the form of availability of parking slots and display routes between users with parking.

The Finding Parking app also includes a payment system created using the VB.Net programming language.this application is located at the entrance gate and exit design gate.where the car works into the parking lot will be recorded the identity of the car such as license plate, type of car and time of arrival by employees, then at the exit gate there is also a payment application which will be calculated parking fees charged.

Finding Parking application is also integrated with the prototype (maket) of the parking lot, the prototype is available 3 parking slots each of the slots are given infrared sensors to detect the presence or absence of the car.the value of the sensor is then sent to the Finding Parking application via an internet connection. The general description is illustrated as shown in Figure 2.2.

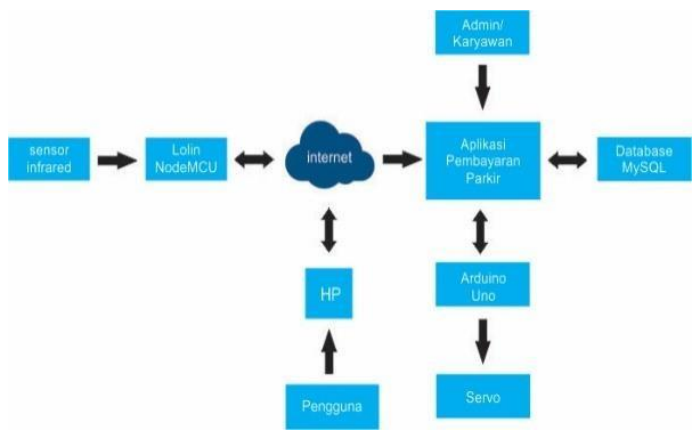

Figure 2.2 System Overview

\subsection{Block Diagram}

Block diagram is used to describe the workings of the parking finding tool that is arranged in the form of block diagrams. As shown in Figure 2.3 below.

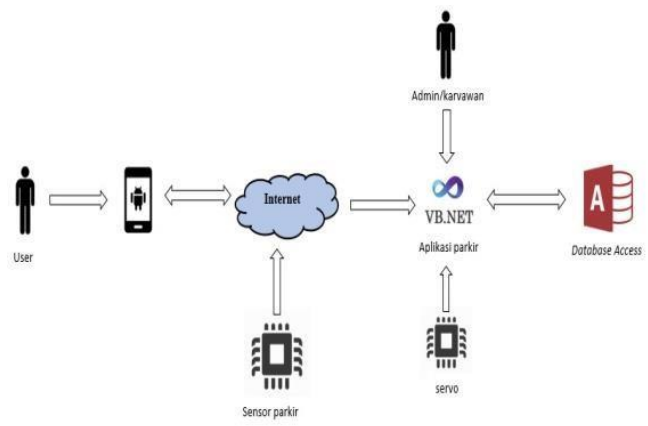

Figure 2.3 Description of Block Diagram Finding Parking

\subsection{Use Case Diagram}

\subsubsection{Use Case Diagram Application Finding Parking}

Here is an overview of the design of the parking space search application system to inform the user of the availability of parking slots at the intended location as shown in Figure 2.4. 


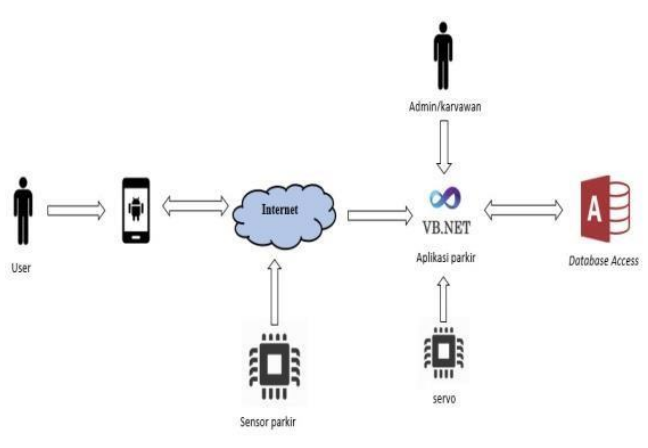

Figure 2.4 Use Case Diagram Application

\subsubsection{Use Case Parking Infrmasi System Application}

Here is an overview of system design Parking Parking System Application as a parking transaction process as shown in Figure 2.5.

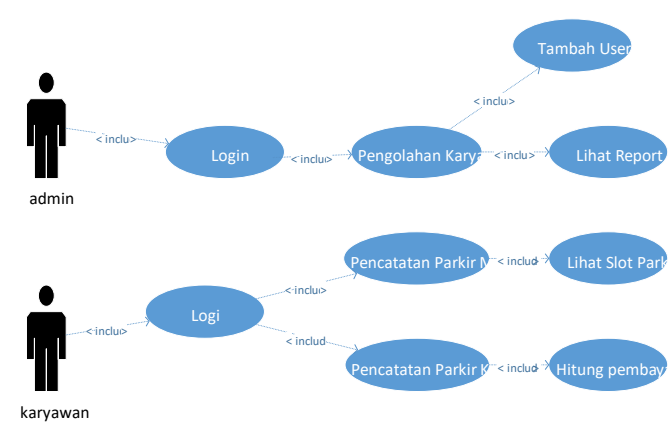

Figure 2.5 Use Case Diagram Application

2.5. Flowchart Modeling

2.5.1. $\quad$ Flowchart Modeling Application Finding

Parking

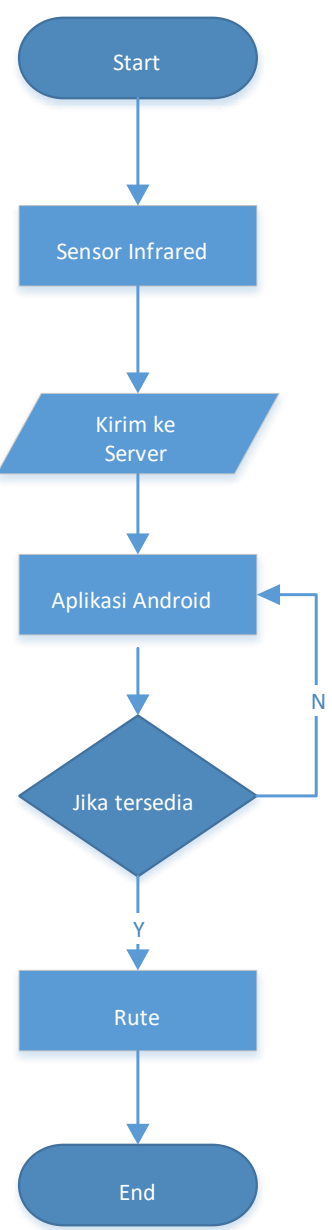

Figure 2.6 Flowchart Modeling Application Finding Parking

2.5.2. Flowchart Modeling Application of Parking Information System 


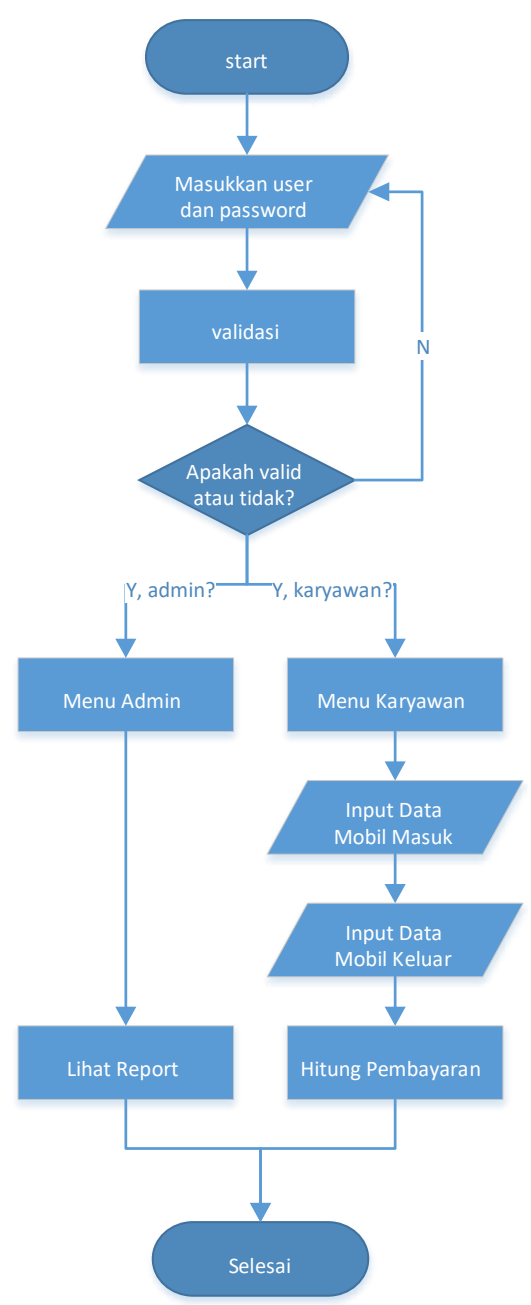

Figure 2.7 Flowchart Modeling Application of Parking Information System

\subsection{Database Design}

2.6.1. User table

Table 2.1 User table

\begin{tabular}{|l|l|}
\hline \multicolumn{1}{|c|}{ Field } & \multicolumn{1}{c|}{ Tipe } \\
\hline Id & integer(11) \\
\hline unique_id & varchar(23) \\
\hline Name & varchar(30) \\
\hline email & varchar(30) \\
\hline encrypted_password & varchar(255) \\
\hline Salt & varchar(10) \\
\hline created_at & Datetime \\
\hline updated_at & datetime \\
\hline
\end{tabular}

\subsubsection{Data of sensor table}

Table 2.2 Data_of sensor table

\begin{tabular}{|l|l|}
\hline \multicolumn{1}{|c|}{ Field } & \multicolumn{1}{c|}{ Tipe } \\
\hline id_sensor & integer (10) \\
\hline Sensor & enum $\left({ }^{*} 0^{\prime}, 1^{\prime}\right)$ \\
\hline sensor1 & enum $\left({ }^{\circ} 0^{\prime}, 1^{\prime}\right)$ \\
\hline sensor2 & enum $\left({ }^{\prime} 0^{\prime}: 1^{\prime}\right)$ \\
\hline created_at & Datetime \\
\hline updated_at & Datetime \\
\hline
\end{tabular}

2.6.3. Table of building

Table 2.3 Table of buildings

\begin{tabular}{|l|l|}
\hline \multicolumn{1}{|c|}{ Field } & \multicolumn{1}{c|}{ Tipe } \\
\hline id_gedung & integer(11) \\
\hline Gedung & varchar(40) \\
\hline Thumb_url & varchar(40) \\
\hline Lat & varchar(30) \\
\hline Long & varchar(30) \\
\hline
\end{tabular}

\subsubsection{Table of login}

Table 2.4 Table of login

\begin{tabular}{|l|l|}
\hline Field & Tipe \\
\hline Id & Auto number \\
\hline admin & varchar (30) \\
\hline karyawan & varchar (30) \\
\hline password & varchar (30) \\
\hline
\end{tabular}

\subsubsection{Parking table}

Table 2.5 Table of parking

\begin{tabular}{|l|l|}
\hline Field & Tipe \\
\hline id & Autonumber \\
\hline tanggal & varchar (11) \\
\hline platNomor & varchar (10) \\
\hline keterangan & varchar (50) \\
\hline JamMasuk & varchar (8) \\
\hline JamKeluar & varchar (8) \\
\hline LamaParkir & varchar (8) \\
\hline Biaya & varchar (5) \\
\hline
\end{tabular}

\section{Results and Discussion}

\subsection{Functionality Testing Results}

Testing functionality is done to find out whether the application and the tool is running as desired, obtained the results shown table 3.1 and 3.2.

Table 3.1 Testing Results Designed Build Finding Parking Tool 


\begin{tabular}{|l|l|l|l|l|}
\hline No & Pengujian & Tujuan & Indikator & Hasil Pengujian \\
\hline 1 & Uji Koneksi & $\begin{array}{l}\text { Mengetahui } \\
\text { apakah alat } \\
\text { dan server } \\
\text { dapat } \\
\text { terhubung }\end{array}$ & $\begin{array}{l}\text { Indikasi } \\
\text { pengujian ini } \\
\text { berhasil bila } \\
\text { antara database } \\
\text { pada server dan } \\
\text { alat dapat } \\
\text { terhubung } \\
\text { sehingga dapat } \\
\text { mengirimkan } \\
\text { data. }\end{array}$ & Berhasil \\
\hline 2 & $\begin{array}{l}\text { Uji Sensor } \\
\text { Infrared }\end{array}$ & $\begin{array}{l}\text { Mengecek } \\
\text { apakah sensor } \\
\text { infrared dapat } \\
\text { mendeteksi } \\
\text { keberadaan } \\
\text { benda. }\end{array}$ & $\begin{array}{l}\text { Indikasi } \\
\text { pengujian ini } \\
\text { berhasil apabila } \\
\text { sensor infrared } \\
\text { dapat } \\
\text { memperoleh } \\
\text { data keberadaan } \\
\text { benda } \\
\text { didepannya. }\end{array}$ & Berhasil \\
& & & \\
\hline
\end{tabular}

Table 3.2 Testing Results Application Finding Parking based on Android

\begin{tabular}{|l|l|l|l|l|}
\hline No & Pengujian & Tujuan & Indikator & Hasil Pengujian \\
\hline 1 & Uji Registrasi & $\begin{array}{l}\text { Memastikan } \\
\text { bahwa data } \\
\text { yang } \\
\text { dinputkan } \\
\text { user berhasil } \\
\text { masuk ke } \\
\text { database. }\end{array}$ & $\begin{array}{l}\text { Indikasi } \\
\text { pengujian ini } \\
\text { berhasil apabila } \\
\text { muncul } \\
\text { pemberitahuan } \\
\text { data berhasil } \\
\text { disimpan. }\end{array}$ & Berhasil \\
\hline 2 & Uji Login & $\begin{array}{l}\text { Memastikan } \\
\text { bahwa data } \\
\text { user yang telah } \\
\text { diinputkan } \\
\text { dapat } \\
\text { digunakan } \\
\text { untuk login. }\end{array}$ & $\begin{array}{l}\text { Indikasi } \\
\text { pengujian ini } \\
\text { berhasil apabila } \\
\text { user berhasil } \\
\text { masuk ke sistem } \\
\text { (halaman utama } \\
\text { aplikasi). }\end{array}$ & Berhasil \\
\hline 3 & $\begin{array}{l}\text { Uji Menu } \\
\text { Parking Places }\end{array}$ & $\begin{array}{l}\text { Mengetahui } \\
\text { bahwa data } \\
\text { yang telah } \\
\text { tersimpan pada } \\
\text { database dan } \\
\text { pembacaan } \\
\text { sensor dapat } \\
\text { ditampilkan } \\
\text { pada listview. }\end{array}$ & $\begin{array}{l}\text { Indikasi } \\
\text { pengujian ini } \\
\text { berhasil apabila } \\
\text { data yang } \\
\text { terdapat pada } \\
\text { database sesuai } \\
\text { dengan data } \\
\text { yang } \\
\text { ditampilkan di } \\
\text { listview. }\end{array}$ & Berhasil \\
\hline
\end{tabular}

\subsection{System Analysis}

In this section discussed about the analysis system Finding Parking Application Parking Parking based on Android and Application of VB.Net based Parking Information System.

\subsection{1. $\quad$ Login page and register}

The login page will appear when the user has not logged on the system.the display results from the login page can be seen in Figure 3.1

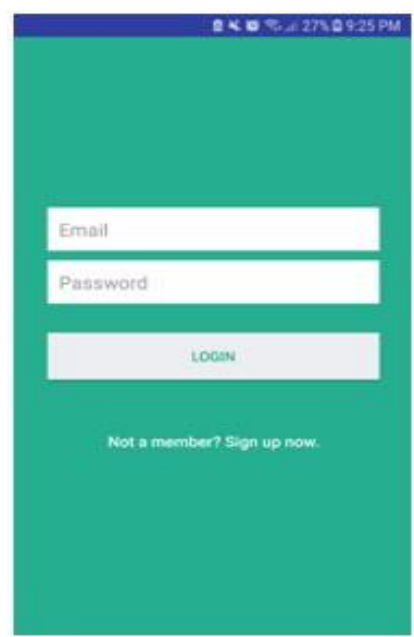

Figure 3. 1 Display Login Finding Parking

\subsubsection{Register page}

The registration page will be displayed if the user wants to register themselves in order to have access rights to enter the application. The results of the register page display can be seen in Figure 3.2.

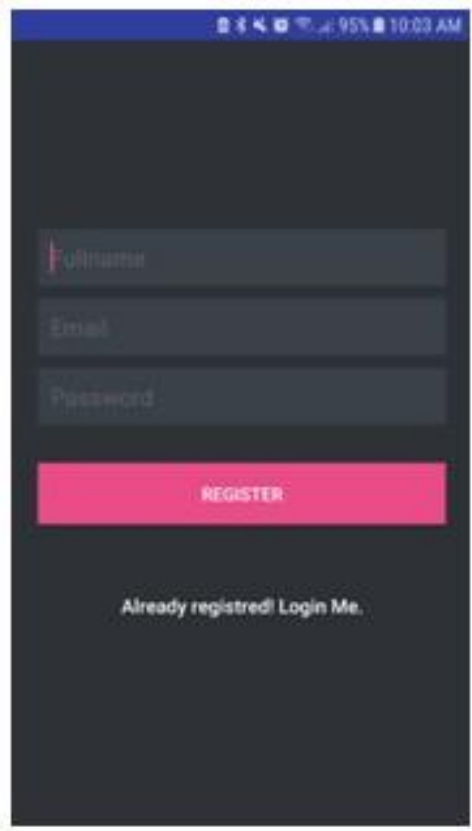

Figure 3.2 Display Register Finding Parking

\subsubsection{Parking Place Pages Menu}

On the menu parking places presented data from the existing parking space and parking availability as shown in Figure 3.3 


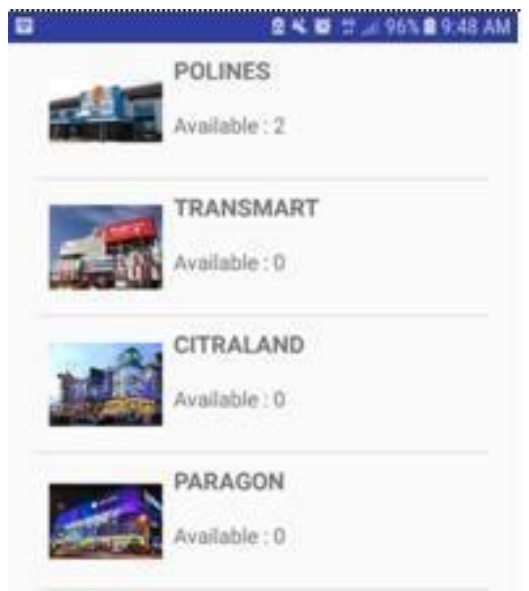

Figure 3.3 View Menu Parking Places Finding Parking

\subsubsection{Maps Menu Page}

Menu maps will appear when choosing a building parking on listview, display menu maps as in Figure 3.4.

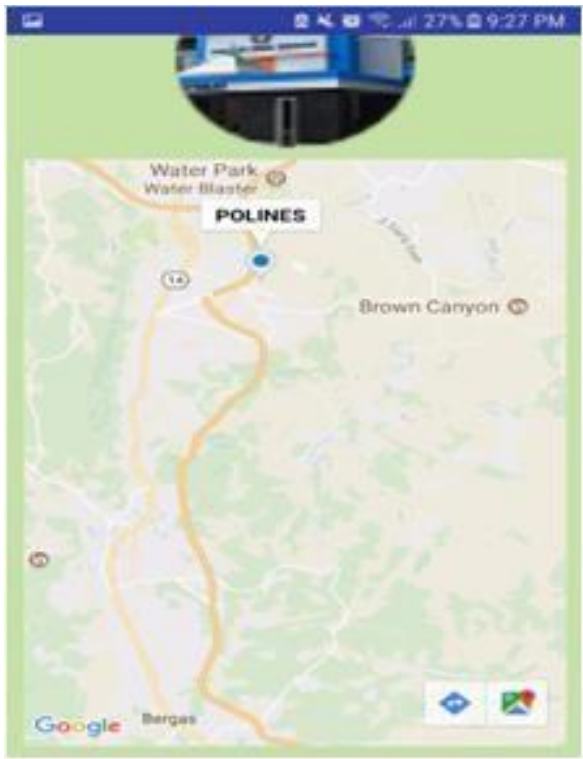

Figure 3.4 Display Menu Maps Finding Parking

The maps menu will appear when the user chooses the desired parking space, then maps will show the location of the parking building along with the route to the location.

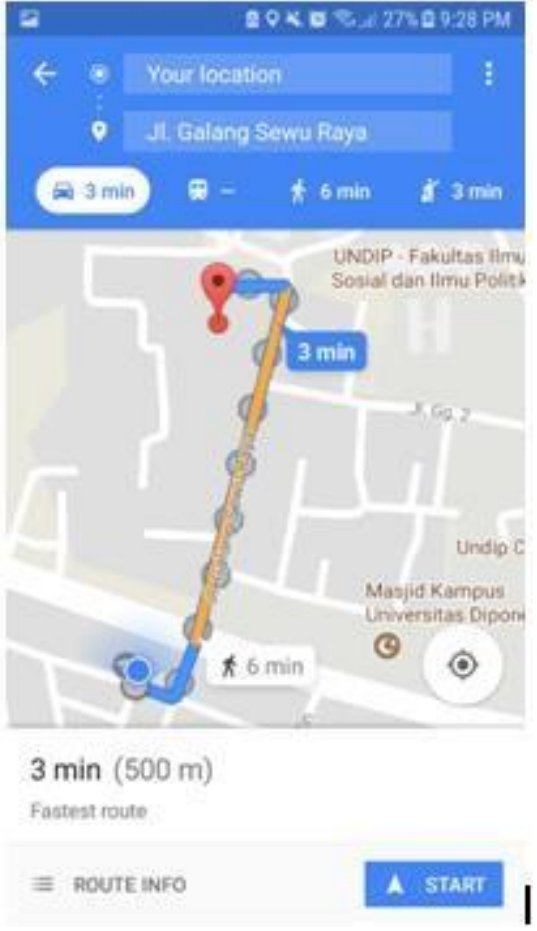

Figure 3.5 Display Route Towards Parking Building Location

\subsubsection{Login page}

The login page appears first before entering the Parking Information System Application as shown in Figure 3.6

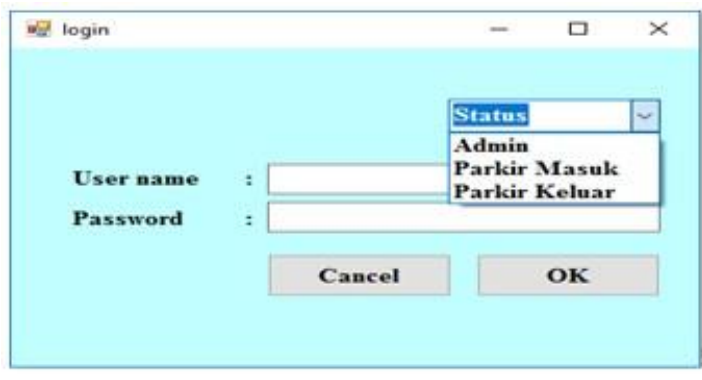

Figure 3.6 Views Page Login Parking Parking System Application

\subsubsection{Incoming Parking Transaction Page}

Incoming parking transaction page appears when the user logs in as an entry parking attendant on the login menu, the incoming transaction page view is shown in Figure 3.7 


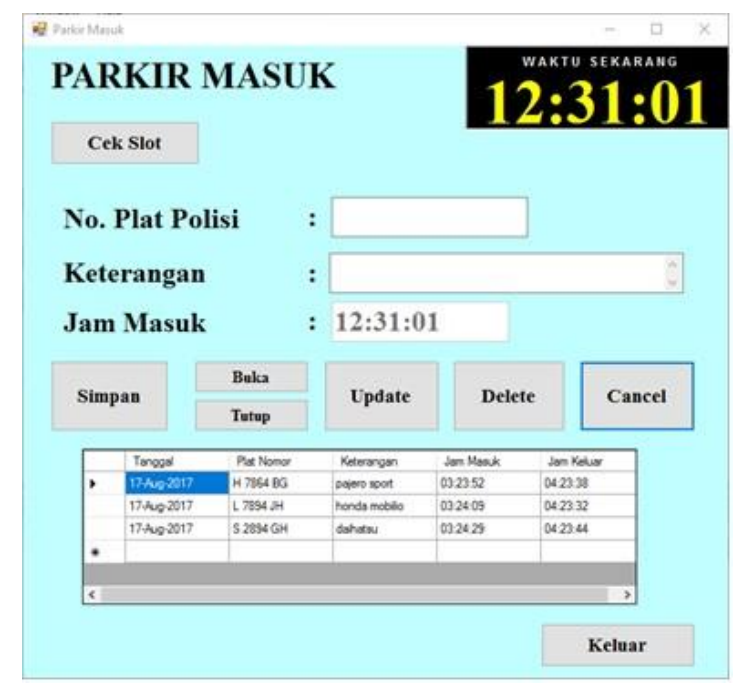

Figure 3.7 Display of Incoming Parking Transaction Page

\subsubsection{Parking Check Slot Page}

Check the tamil parking slot when pressing the ck slot button on the entrance parking page, the check view of the parking slot shown in Figure 3.8

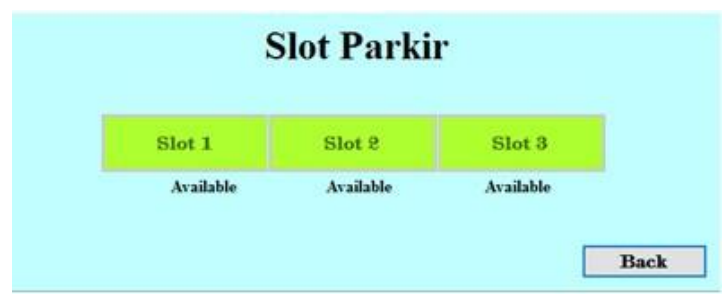

Figure 3.8 Slot Check Page View

\subsubsection{Parking Transaction page out}

The outbound parking transaction page shows up when the user enters as the incoming parking attendant on the login menu, the outgoing transaction page view is shown in Figure 3.9

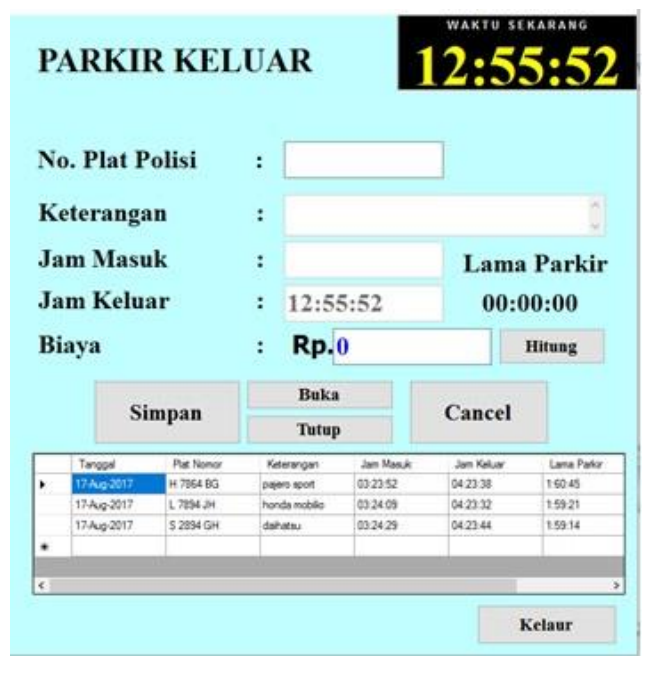

Figure 3.9 Exit Parking Transaction Page View

\subsection{Tool Implementation}

Realization of hardware design in the form of hardware design and assembly of modules, starting from the installation of Wi-Fi module that is Lolin or NodeMCU for data communication between mobile application and desktop application.then assembly of the main sensor that is infrared sensor (PIR). Tool implementations are shown in Figures

3.10 and 3.11

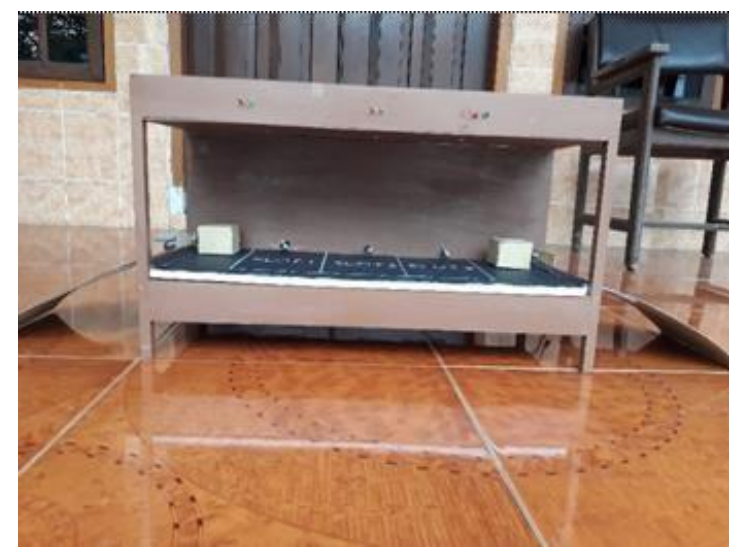

Figure 3.10 Image Design of Front View Tool 


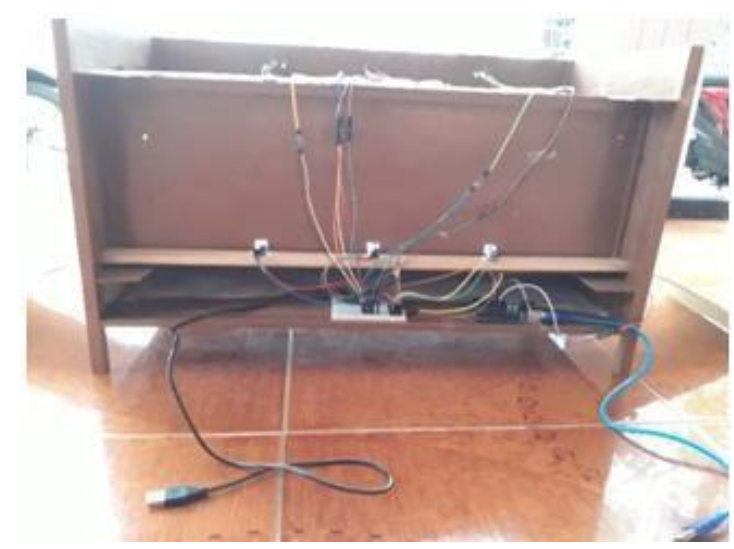

Figure 3.11 Picture Design of Inside Display Tool

\subsection{Test Results of User Satisfaction Level}

At this stage contains the results of testing the Finding Parking Application system can be seen in Table 3.11

\begin{tabular}{|l|l|l|l|l|l|l|l|l|}
\hline \multirow{2}{*}{ No } & \multirow{2}{*}{ Nama } & \multicolumn{6}{|c|}{ Daftar Pertanyaan } & Total \\
\cline { 3 - 8 } & & 1 & 2 & 3 & 4 & 5 & 6 & Nilai \\
\hline 1 & Annisa Fitri Aji A & 3 & 3 & 4 & 4 & 4 & 4 & 22 \\
\hline 2 & Boby Adhi W & 3 & 4 & 4 & 3 & 4 & 3 & 21 \\
\hline 3 & Zulhilmi Lutfi & 3 & 3 & 4 & 3 & 4 & 4 & 21 \\
\hline 4 & Bagus Guritno & 3 & 4 & 3 & 4 & 4 & 4 & 22 \\
\hline 5 & Nurul Dwi Riana & 3 & 4 & 4 & 5 & 3 & 4 & 23 \\
\hline 6 & Samifra Ginting & 4 & 4 & 3 & 5 & 4 & 4 & 24 \\
\hline 7 & Fahran Ramadan & 3 & 3 & 4 & 4 & 5 & 4 & 23 \\
\hline 8 & Radix Cita MN & 5 & 4 & 4 & 5 & 5 & 5 & 28 \\
\hline 9 & Berly & 3 & 4 & 4 & 4 & 5 & 4 & 24 \\
\hline 10 & Alif & 4 & 4 & 4 & 5 & 4 & 5 & 26 \\
\hline 11 & Hana Seira V & 4 & 3 & 3 & 3 & 4 & 5 & 22 \\
\hline 12 & Miftahul Fitri & 4 & 5 & 4 & 5 & 4 & 4 & 26 \\
\hline
\end{tabular}

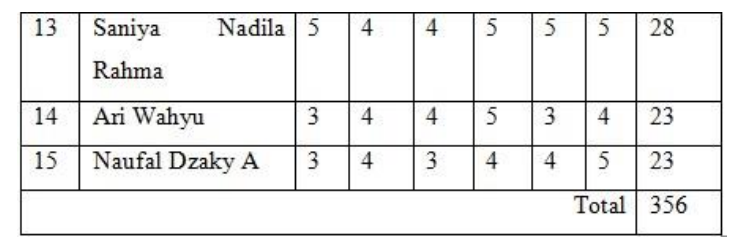

From the above opinion results obtained value of $79.11 \%$. Based on Table 4.4 can be categorized as satisfactory, so this application as expected and can be used as needed.

\section{Conclusion}

Based on the results of this Final Project, it can be concluded that has managed to create an Androidbased Finding Parking Application designed using Java programming using MySQL database as a server is useful as a parking location search application by providing routes from users to the parking lot and also managed to make Information System Application Desktop-based parking is designed using VB.Net programming using the MySQL database as handy for managing parking lots.

\section{Bibliography}

[1] Badan Pusat Statistik. (2016). Statistik Transportasi Darat 2015, 67. Retrieved from

https://www.bps.go.id/website/pdf_publikasi/StatistikTransp ortasi-Darat-2015.pdf

[2] Hermayadi. (2013). Prototipe Sistem Parkir Otomatis berbasis Mikrokontroler ATMEGA-16. Yogyakarta, (1),

1-5. https://doi.org/10.1007/s13398-014-0173-7.2

[3] Imbiri, F. A., Taryana, N., \& Nataliana, D. (2016).

Implementasi Sistem Perparkiran Otomatis dengan Menentukan Posisi Parkir Berbasis RFId. Jurnal ELKOMIKA, 4(1) 